\title{
Archaeological University Education and Professional Archaeology in Sweden
}

Stig Welinder

\begin{abstract}
During the $19^{\text {th }}$ century very few persons in Sweden recieved a doctoral degree in archaeology. Most of them found prestigious top-positions. Today there are about 100 persons with Ph.D.'s working in Swedish archaeology in positions from the top to the bottom of the professional hierarchy. Each year 150-200 students finish their basic education in archaeology. Most of them will never find a permanent full-time job as an archaeologist. The future of Swedish archaeology will very much depend on the ambitions of the general public, including tens of thousands of persons with a formal university education in archaeology but no job within the profession.
\end{abstract}

Stig Welinder, Department of Humanities, Mid Sweden University, SE83125 Östersund, Sweden.

The dissertation by Hans Hildebrand from 1866 is normally regarded as the first in archaeology in Sweden. Oscar Montelius defended his thesis in 1869. Thus the $1860 \mathrm{~s}$ saw the start of professional archaeology conducted by university-educated archaeologists in Sweden. The first chairs in archaeology were established in 1914 and 1919, when Oscar Almgren and Otto Rydbeck were appointed professors at Uppsala University and Lund University, respectively. Thus the 1910 s saw the establishment of archaeological departments at the universities, in both cases as parts of century-old historical university museums (Rydbeck 1943; Schönbeck 1956; Gräslund \& Almgren 1976; Stjernquist 1984).

This article will outline the archaeological university education in Sweden primarily from a quantitative point of view as concerns the number of students. Education will be related to the professional labour market at universities, museums and cultural-heritage management institutions. The stress will be on the ambitions and prospects of the youth of the 1990s.

In contrast to the 1910 s, there are today a total of five universities and four university colleges (Sw. högskolor) to choose among when striving for an archaeological education and career in Sweden (figs. 1-2). The increase in number is a result of the political ambition since the 1960s to increase the rate of higher education, and make it locally available in most of the country. The number of university colleges has increased tremendously, and a few of them have been turned into universities during the 1990s. Most university colleges and some universities, however, do not teach archaeology. Only universities bestow doctoral degrees. 


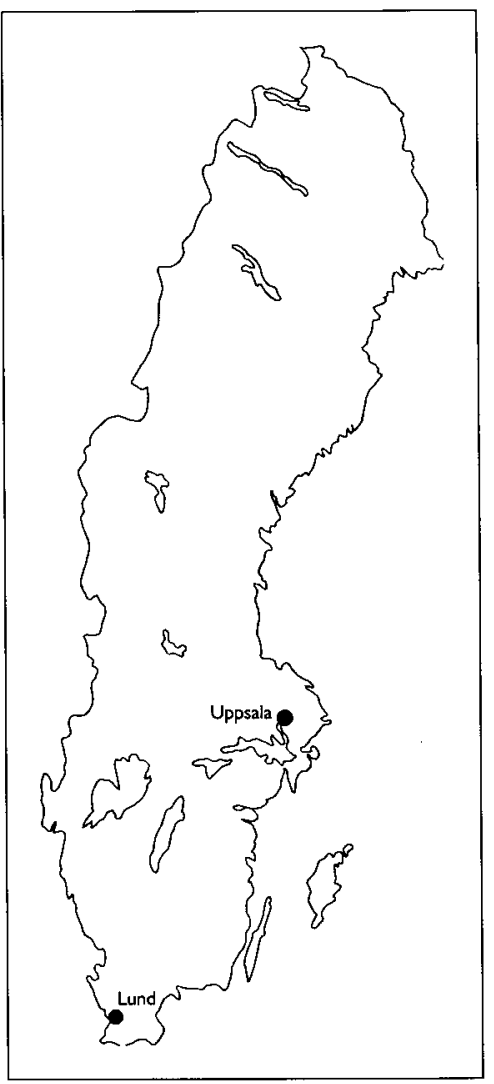

Fig. 1. Universities with chairs in archaeology combined with historical university museums in 1920.

\section{DEGREES AT THE RESEARCH LEVEL 1860-1998}

Very few persons recieved a doctoral degree in Sweden prior to 1910 (fig. 3). At about that time the first academic seminar, following the tradition of the mid- $19^{\text {th }}$ century Berlin seminar by Leopold von Ranke, was formed at Uppsala University around Oscar Almgren and Knut Stjerna. The common interest of that group of scholars was the early pioneer settling and the consecutive settlement history of Sweden. Theses were presented, each discussing one province, e.g. Nils Lithberg (1914), Gunnar Ekholm (1915), and Karl Einar Sahlström (1915). The first thesis defended by a woman, Hanna Rydh (1919), treated box-shaped brooches.

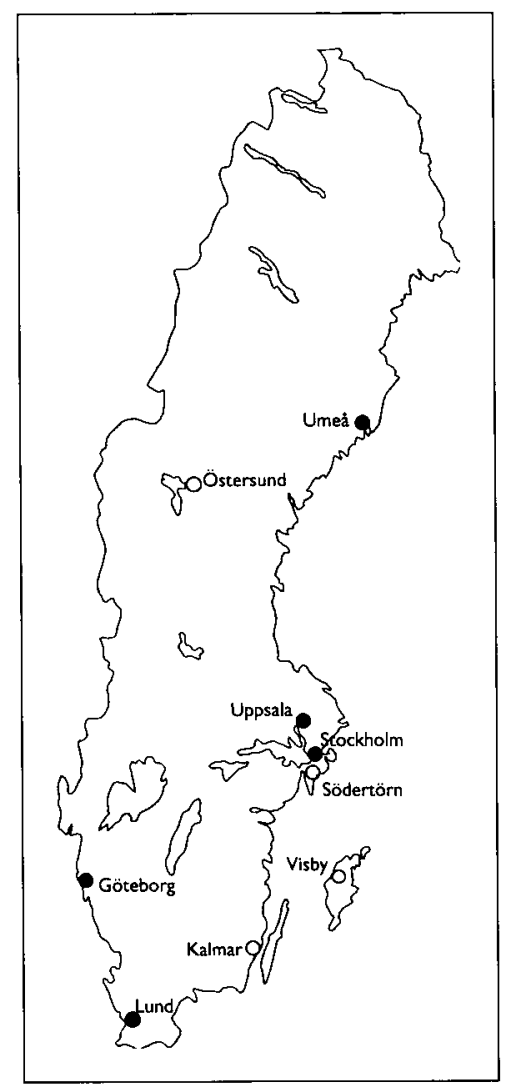

Fig. 2. Universities with archaeology departments (points) and university colleges with archaeological education organised in various ways (circles) in 1999.

During the $1970 \mathrm{~s}$ the number of theses increased from about one a year to about three. One main reason was the introduction in 1970 of a new degree meant to correspond to a British or American Ph.D., and thus in theory possible to finish in a much shorter time than the traditional degree. The first theses according to these new regulations were by Jonas Ferenius (1971), Agneta Lundström (1971) and Stig Welinder (1971). The last year to defend a thesis for the traditional degree was 1974.

The new regulations were part of a series of academic reforms that aimed at a more democratic university system and at paving the way for new groups of potential students 


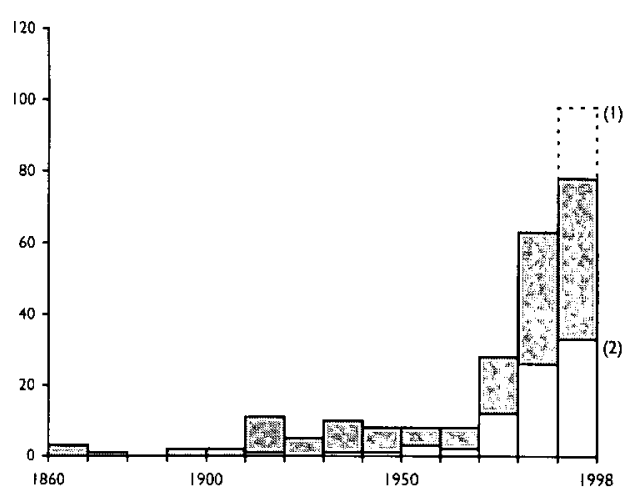

Fig. 3. Master's theses (until 1864) and doctoral theses in archaeology defended at Swedish universities (partly from Wahlberg 1877; Kyhlberg 1982). (I) = linear prognosis until 2000, (2) = theses defended by women.

from segments of the Swedish society with no previous experience of university education. Obviously the number of theses increased, and so did the percentage of theses defended by women (fig. 3).

The theses by female students were written by a new generation of women born in the 1940s with ambitions to combine university education with establishing a family and raising children. Actually, during a few years in the early 1970 s more theses were defended by women than by men (tab. 1). Examples are Elisabeth Iregren (1972) and Lillemor Lundström (1973). Some of these women have, in personal letters, described how they did not feel themselves to be in a peculiar position as women: Archaeology was fun and archaeological research was fun. One of them, however, stated that the first female professor, Greta Arwidsson at Stockholm University, was of great help. That does not seem to have been typical. The idea of female mentors promoting female students has no obvious support in Swedish archaeology, at least not around 1970 .

The many new doctors of philosophy in the 1970s was the result of a new educational system and a new society with more demo- cratic possibilities, including new possibilities for women to carve out careers. To some extent it was Social Democratic governmental politics.

In one sense the new system failed. Before 1974 new doctors of philosophy normally were $30-40$ years old. After 1974 they were not any younger. The mean age in fact was a little higher than before 1974 (Nordbladh 1991:figs. 9-10). Scores of students registered as Ph.D. candidates ( $\mathrm{Sw}$. doktorand) during the 1970s and 1980s. In the mid-1980s there were 200 registered doktorander in archaeology at the five universities (Nordbladh 1991:fig. 3). Most of them have never finished a thesis. They were about $30-35$ years old and working within the growing culturalheritage bureaucracy. To register as a doktorand and to plan a thesis developed into a life-style. Attending seminars and being known as a doktorand helped them keep a stiff upper lip in the daily bureaucratic routine. With an increasing number of children and an increasing baldness the thesis turned into a dream. It became rather the end than the beginning of a career, if it was ever finished.

The two obvious steps in the increase curve of the number of archaeological theses defended during the 1910s and the 1970s (fig. 3 ) are not entirely typical of the humanistic disciplines as a whole in Sweden. In history and related disciplines two steps occurred during the $1930 \mathrm{~s}$ and the 1960s (Odén 1991:diagram 1). The increase in the percentage of theses written by women was notably less compared with archaeology (Blom 1978:diagram 3).

\begin{tabular}{lcc} 
& Women & Men \\
\hline $1970-1974$ & 8 & 7 \\
$1975-1979$ & 4 & 9 \\
\hline
\end{tabular}

Tab. 1. Doctoral theses in archaeology defended by women and men at Swedish universities 19701979 (cf. fig. 3). 
(1)

(2)

(3)

(4)

(5)

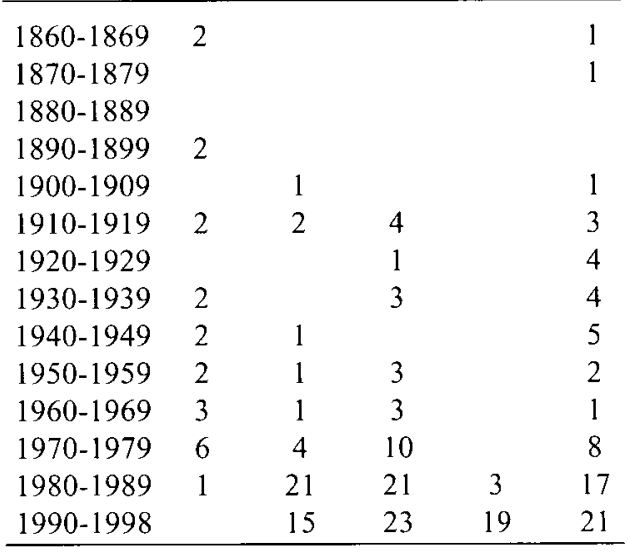

(1) = riksantikvarie, professor; (2) = other university positions; (3) = head of museum, curator, antiquarian; (4) = no employment, short-term employment; (5) = not in Swedish archaeology

Tab. 2. Positions achieved by doctors of philosophy in archaeology at Swedish universities 1860-1998.

The situation in the $1980 \mathrm{~s}$, outlined above, is the outcome of the simple fact that not since the 1860 s has a doctoral degree been a prerequisite for a career within Swedish archaeology, and it has never been a guarantee (tab. 2).

Of the six archaeologists with a Ph.D. in the $19^{\text {th }}$ century three became Head of the Central Board of National Antiquities (Sw. riksantikvarie) one after the other, one became the first university professor of archaeology, and two left archaeology after many years spent within the discipline, one to become a high school headmaster, the other to become curator at the State Museum of Ethnography. There was no room for more archaeologists educated at the highest level in Swedish archaeology. Thus Gabriel Gustafson never finished a degree. In 1889 he went to Norway, later to become a professor in Oslo (Welinder 1998:8).

Of the relatively many doctors of philosophy from the 1910 s the majority got positions as antiquarians at the National Museum of Antiquities in Stockholm or positions at the university departments, although the only one to become a professor was Sune Lindqvist, who got the chair in Uppsala after Oscar Almgren. Some of them never got positions. One was Hanna Rydh. She was married to an antiquarian at the Stockholm museum. That museum composed the entire archaeological labour market in Stockholm. Thus, it was impossible for her to get a position in archaeology, because a married couple was unthinkable in the same place of work.

A quick glance at the period 1920-1949 in table 2 demonstrates the above statement. The majority of the persons with a Ph.D. never got positions within archaeology. During this time the accepted career was to write a thesis, get a position as a senior lecturer (Sw. docent), which was a six-year research scholarship at a university department, and then a professorship. When you failed to cross either of these two thresholds, you left archaeology. This is valid for some of the doctors of philosophy from the period. Others never strived for an archaeological academic career. There are other reasons for writing a thesis.

During these decades it was the norm to try for an intermediate degree (Sw. filosofie licentiatgrad). Its requirements were, in theory, a study period of 2-3 years and a small thesis. This degree was the prerequisite for most of the prestigious positions within the cultural-heritage management bureaucracy and the regional and national museums. There are no available data on the number of students that received this degree before about 1950 . The degree was abandoned when the new doctoral degree was introduced. In the period 1950-1974 the degree was given to 38 students, out of which 14 were women. I do not know the life stories of these persons.

In the 1950s and 1960s it was more or less self-evident that the doctor's degree was part of a prestigious archaeological career, the end of which was a university position or a position as head of a regional museum. 
There are few exceptions. Of the three doctors of philosophy that left archaeology, one founded a more or less private archaeological laboratory doing research in close connection to the commercial world, and one inherited one of the biggest private fortunes in Sweden, which he successfully increased as an industrialist.

The 1970s saw no obvious change. The archaeologists with Ph.D.'s, however, often did not get final positions as heads of museums, but rather as curators, and some left archaeology to get positions at museums in other fields. Some got positions abroad.

Perhaps it is too early to evaluate the 1980 s and, rather obviously, the 1990s. I see, however, two typical kinds of doctors of philosophy during the latter decade. There are those, who have written their thesis parallel to a paid full-time job. Perhaps they have had a research scholarship for a few years, and all in all they have spent $10-15$ years writing the thesis. When they finally get their degree, they more or less continue in the same job with a little higher pay per month. These are the doktorander that registered during the 1970s, and actually have been successful as concerns their dream. Others started on their doctoral education in the late 1980 s without having a job, except for occasional field-work and other temporary work. After they have completed their thesis their situation have remained more or less the same. They do not get permanent full-time positions, and certainly not the most prestigious ones.
The latter group is a phenomenon more or less unknown before the $1990 \mathrm{~s}$. The group consists of students interested in doing archaeological research and accordingly trying for a degree, but a growing number of students that have finished the basic university education do not find a job within archaeology or the cultural-heritage management bureaucracy: instead, they register as doktorander. A few have managed to finish their thesis before becoming absorbed full-time in paid jobs or raising families. For most of these doktorander, the academic type of research scholarship for doktorander that pays for 34 years of doctoral studies has been useful.

The first group was typical also of the 1980s, but many of the doctors of philosophy of that decade are today also found in positions as lecturers at the archaeological university departments. One of them has managed to get a professorship, namely Kenneth Jonsson at Stockholm University (1987), specialising in numismatics. The doctors of philosophy from the 1990s that are found among the staff of the departments, on the other hand, mostly hold temporary positions.

There is a, hopefully not long-term significant, trend that the tendencies outlined above are more valid for female doctors of philosophy than for male ones (tab. 3). The share of the persons with a Ph.D. that have found a satisfactory job within archaeology has declined less for men than for women since the 1980s.

A large share of the doctors of philosphy
(1)

\begin{tabular}{cccc}
\hline $1980-1989$ & $\mathrm{~F}$ & & 3 \\
& $\mathrm{M}$ & 3 & 35 \\
$1990-1998$ & $\mathrm{~F}$ & & 18 \\
& $\mathrm{M}$ & 20 \\
\hline
\end{tabular}

(3)

38

30

24

33

(4)

\begin{tabular}{cccc}
4 & 27 & 100 & 26 \\
5 & 27 & 100 & 37 \\
27 & 30 & 99 & 33 \\
22 & 26 & 101 & 45 \\
\hline
\end{tabular}

(1) = riksantikvarie, professor; (2) = other university positions; (3) = head of museum, curator, antiquarian; (4) = no employment, short-term employment; (5) = not in Swedish archaeology

Tab. 3. Positions achieved by female and male doctors of philosophy in archaeology at Swedish universities 1980-1998 (percentages). 
from the latest two decades have found positions abroad. Many of them are citizens of other Nordic countries, who have spent their university years in Sweden and returned home after having earned their degree. Some are scholarship students from African countries, who have been invited by SAREC, the Swedish Agency for Research Cooperation in Developing Countries, to study at the Department of Archaeology at Uppsala University.

Finally, it is notable that writing a thesis in archaeology has become an occupation for retired people and ambitious housewives with grown-up children.

A century ago there was a handful of archaeologists with a doctoral degree at a few prestigious positions at the central institutes in Stockholm and soon at the universities, too. Most of them belonged to a segment of the middle class with academic traditions and often a private fortune to pay for their education. Still during the 1960 s there were not more than about a dozen people with a doctoral degree working in Swedish archaeology as professors, heads of museums, or as antiquarians at the national institutes in Stockholm.

The 1970s saw the beginning of the big change. Today there are about 100 persons with a doctoral degree employed in Swedish archaeology. They are found everywhere in the system: in chairs and other university positions, in national and regional museums, in the cultural-heritage management bureaucracy ... from top positions to close to the bottom. Thus, well-educated archaeologists can increasingly be seen in influential positions as well as routine-work positions in Swedish archaeology. The reason is not an explicitly phrased demand for people with a doctoral degree on the part of the employers. Rather it is the opposite. Most employers outside the universities and university colleges prefer people with 5-10 years of experience in a museum or another relevant place of work, to people who have spent 5-
10 years writing a thesis. However, today it is difficult to get a job. So instead people write theses.

The set of persons with a Ph.D. in archaeology in Sweden today, most probably reflects the segment of the Swedish population which has received university education and degrees. Typically, they have a middle-class background with parents with academic education, although they are the first in their family to get a doctoral degree. They reflect the general growth in university education in Sweden during the later half of the 1960s, parallel to the growth of Sweden into one of the most prosperous nations in the world.

This is still more evident from the statistics on the basic education.

\section{BASIC EDUCATION AFTER 1950}

It is more or less unknown how many students of archaeology there are in Sweden today. There are also no reliable long-term statistics (Welinder 1991). A few years ago, however, a rough estimate suggested there to be about 500 beginners in prehistoric archaeology, about 30 in medieval archaeology, and about 400 in classical studies. All in all, about 250 each year finished their third term, and a little more than 100 completed a fourth term (Welinder 1995, table 2).

Until the 1960s the basic archaeological university education was fairly informal. The students attended a few lectures and seminars during a few terms. There were oral exams, and the educational program was finished by presenting a seminar paper during the third term at the earliest, or some time later. In 1973 a formal system with A-, B- and C-level terms was introduced (Lamm 1978:320). Today many students also attend a D-level term.

Until recently the archaeological education was regarded as part of a general culturalhistorical and museological education of about 6-8 terms with subjects like art history and ethnology, in addition to archaeology. Since the late 1980s an increasing number 
of students go to university with the intention of becoming an "archaeologist". The basic education, however, is still the same. The students study four terms of archaeology and another four terms of a free choice of relevant subjects. They write a master's thesis, that is a CD- or D-paper written during two or one term, respectively. After that some become "archaeologists", while others with essentially the same education get positions in a variety of museums or the cultural-heritage management bureaucracy, or quite other positions. I will come back to that.

There are very few seminar papers from before 1950 found in the public archives (Lamm 1972:19-20; Lamm \& Spetz 1994:8). From that time on, however, reliable statistics are available (fig. 4).

The quantum leap in university education during the late $1960 \mathrm{~s}$ is obvious from the number of students presenting $\mathrm{C}$ - and Dpapers during the 1970s. The way into the universities was smoothed for large groups of new students. A new financial system

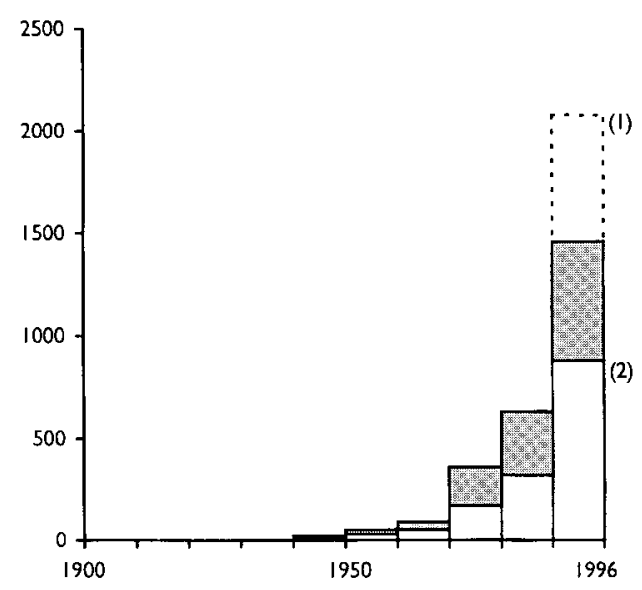

Fig. 4. Students presenting seminar papers in archaeology, prehistoric and medieval, at Swedish universities 1900-1996 (from Lamm 1972, 1978, 1984: Lamm \& Spetz 1994; Rundkvist 1998). Students presenting more than one paper are noted only once. The data are incomplete before ca. 1950. (1) = linear prognosis until 2000, (2) = theses defended by women. which enabled the students to get loans was introduced, extramural university courses grew in number, a more school-like teaching system was introduced, many new part-time lecturers were appointed, and the students were directed to cut their numbers of terms at university. The terms were divided into courses, each with its own written exam.

The 1990s saw another quantum leap (fig. 4). Today hundreds of students finish a threeor-four-term education in archaeology. They are the sequel to an enormous rise in public interest in archaeology during the 1980s. Archaeology became a highlight of TV, newspapers, and periodicals. Archaeology became a regular part of the schoolcurriculum for 10-11 year old pupils. The number of visitors at exhibitions and the local interest in excavations increased. The reason for this development has not yet been thoroughly examined in Sweden, but in connection with the establishment of archaeological education at a number of university colleges (fig. 2), and the political effort to keep people out of the unemployment statistics, the result was an increase in the number of archaeology students.

Simultaneously the norm has changed from a basic education of three terms to four, from the C-level to the D-level. The D-level, that is four terms of archaeology and a master's degree, is the normal education for the main part of the labour force entering Swedish archaeology today.

The discipline of classical studies has seen about the same increase in the number of students as prehistoric archaeology (fig. 5). The increase in the 1990s is, however, less pronounced.

The students of the 1990s are sometimes the first to go to university in their families, and when they are not, they are often the children of those that attended university as the first ones in the 1960s or 1970s. The latter group of students was unlucky with poor teachers and poor teaching in too big classes at too fast expanding universities. There was, 


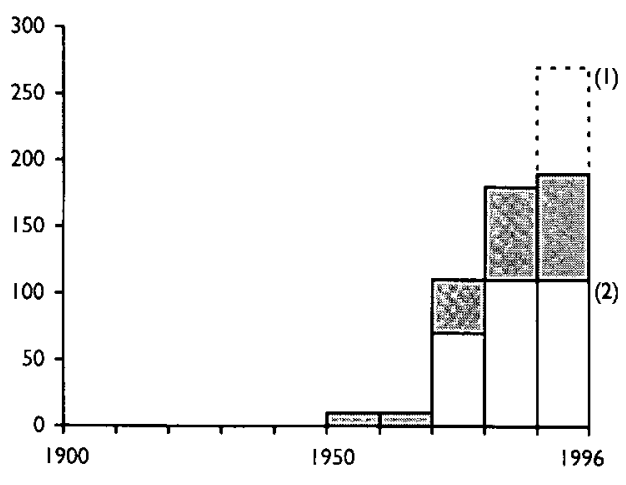

Fig. 5. Students presenting seminar papers in classical archaeology (classical studies) at Swedish universities 1900-1996 (from Lamm 1972, 1978, 1984; Lamm \& Spetz 1994; Rundkvist 1998). Students presenting more than one paper are noted only once. The data are incomplete before ca. $1970 .(\mathrm{l})=$ linear prognosis until 2000, (2) = theses defended by women.

however, also the spirit of 1968: left-wing radicalism, feminism, environmental protectionism, the anti-Vietnam protests, Third World solidarity... The new generation of students did not feel at home in the traditional university system, and the traditional university professors did not feel at home in the new system. During the 1970 s formal democracy and efficient bureaucracy were introduced. The universities, for better or worse, turned into modern organisations ready to educate several times as many students as just a generation ago, students that expected to get an adequate education for the labour market and a corresponding salary. They were to be disappointed.

The size of the archaeological labour market in Sweden is not known. One reason is that much of it is poorly delimited. That is valid for the cultural-heritage management bureaucracy, the museums, and much of the regional and local cultural administration. The available positions may be filled by people with archaeology as their main university subject, but ethnology, cultural anthropology, human geography and art history may be as useful and asked for by the employers. A very rough guess is one thousand man-years in archaeology.

Perhaps half of the positions are more or less permanent positions at university departments, museums and other institutions. The other half comprises short-term positions and the seasonal work-force in fieldwork.

The size of the seasonal work-force has varied between ca. 100 and 250 persons in the period 1960-1990 (Magnusson 1991, fig. 1; Welinder 1991, fig. 1). There are no reliable statistics from the $1990 \mathrm{~s}$, but my guess is that about $400-500$ persons were engaged during a few years in the second half of the decade. The reason was an incidental boom in contractor-work: bridges, railways, airport strips etc. It is said that 1998 saw the biggest excavation activity ever in Sweden in a single year. The excavation volume will soon decrease, and accordingly the temporary fairly good opportunities for archaeology students to get seasonal jobs will disappear.

Another interesting phenomenon is that the central recording of ancient monuments has recently been terminated. Nevertheless, vast areas of Sweden are poorly or not at all surveyed. This has instead been done locally, organised by the regional museums, the municipalities or various authorities within forestry. Most often the labour-force conducting these surveys has consisted of unemployed people without previous, adequate archaeological education.

It is notable that there were equally many women and men among the archaeology students already around 1950 (fig. 4). It is also notable that the first quantum leap in the late $1960 \mathrm{~s}$ meant a decrease in female students from $55 \%$ to $46 \%$, while the second quantum leap in the early 1990 s meant an increase from $51 \%$ to $60 \%$ (fig. 4). Gender strategies and gender attitudes have never been studied in depth in Swedish archaeology. It is, however, obvious that gender is a factor of importance.

During the entire period 1965-1989 
women made up about $50-60 \%$ of the seasonal labour-force on excavations (Welinder 1991, fig. 1), that is about the same, or a little more, as the percentage of female students presenting seminar papers. During the same period the percentage of women employed in surveying ancient monuments increased from $0-3 \%$ during the 1960 s to $50-55 \%$ around 1990 (Magnusson 1991, fig. 1). The latter type of work simply was not regarded as suitable for women, while the first type was. This of course meant that it was easier for male students to get their first position.

More sophisticated mechanisms, unconscious and non-intentional at the time, can be hinted at. In the late $1970 \mathrm{~s}$ there was an economic slump, with its low tide mark in 1978 (Welinder 1991, fig. 1). In 1978-1979 the percentage of women in seasonal excavation jobs was $10 \%$ lower than before and after (tab. 4). Female archaeologists in 1977-1978 decided not to continue with seasonal excavation jobs. Alternatively, they were not asked to come back the next season. Whatever the case, the reasons are not known. The total seasonal labour-force grew at the time, as did the number of archaeology students and the percentage of male students. It is a pity that the parallel process during the 1990s cannot be studied due to a lack of statistics.

\begin{tabular}{llll} 
Year & $(1)$ & $(2)$ & $(3)$ \\
\hline 1975 & 40 & 48 & 31 \\
1976 & 41 & 49 & 29 \\
1977 & 60 & 58 & 62 \\
1978 & 57 & 50 & 67 \\
\hline
\end{tabular}

(1) $=$ men in the total labour-force

(2) $=$ the share of re-hired personnel compared to the previous year

(3) $=$ the share of men among the re-hired personnel

Tab. 4. Sex ratios among the seasonal labour-force (percentages) employed by the Central Board of National Antiquities 1975-1978 (from Welinder 1991).
Thus, inequalities between female and male students in relation to the labour market are hinted at. It can also be suggested that female and male students have different interests within archaeology and write seminar papers in different ways (tabs. 5-6).

The main part of the seminar papers discuss artefacts and artefact types as their principal subject (tab. 5), but female students do so more often than male students. Male students have been more interested in settlement sites and settlement patterns. The overall long-term trend from the 1960 s to the $1990 \mathrm{~s}$ is that the writing on artefacts has been most popular. About $40-50 \%$ of all papers were artefact-focused in the 1960s and ' 70 s. In the 1980s and ' 90 s the amount was about $25-30 \%$. Thus, today the papers are more diversified than some decades ago. During the 1980s settlement patterns were in vogue. During the 1990s the discussion of religion, social structure and generally theory and methods has grown in popularity.

The available data on the subjects of the seminar papers do not permit the detection of gender-specific trends. This is, however, possible as concerns writing style (tab. 6). In the 1970s female and male archaeology students wrote seminar papers in the same way. The main part of the papers contained descriptive information. In addition the data

\begin{tabular}{lcc} 
Subject & Women & Men \\
\hline Artefacts & 78 & 53 \\
Burial-grounds & 34 & 21 \\
Theory and methods & 20 & 14 \\
Settlement sites & 15 & 41 \\
Religion and social structure & 13 & 14 \\
Settlement patterns & 12 & 29 \\
Technology & 9 & 10 \\
Culture groups & 7 & 3 \\
Rock-carvings and other pictures & 6 & 16 \\
\hline
\end{tabular}

Tab. 5. The subject of seminar papers by female and male students (number of papers) in archaeology at the C-level 1950-1996 at Lund University (from seminar paper by Annette Wallin). 


\begin{tabular}{ccccccc} 
& \multicolumn{2}{c}{$\begin{array}{c}\text { Descriptive } \\
\text { sentences }\end{array}$} & \multicolumn{2}{c}{$\begin{array}{c}\text { Explanatory and } \\
\text { analytical sentences }\end{array}$} & \multicolumn{2}{c}{$\begin{array}{c}\text { Evaluative and } \\
\text { emotional sentences }\end{array}$} \\
\hline & Women & Men & Women & Men & Women & Men \\
$1970 \mathrm{~s}$ & 77 & 77 & 21 & 21 & 2 & 2 \\
$1990 \mathrm{~s}$ & 59 & 52 & 33 & 34 & 8 & 14 \\
\hline
\end{tabular}

Tab. 6. The writing style (percentage of sentences according to Gunnarsson 1989) of female and male archaeology students at the C-level at Lund University (from seminar paper by Annette Wallin).

were analysed and explained. In the 1990s there is an obvious change. More pages are dedicated to analysis and explanation, less to description. The papers have also become more personal and individual, which is seen as an increase in the number of sentences that express values, commitment and emotions. This is of course an implication of the fact that the post-processual debate has been introduced into the curricula of the various archaeology departments. The trend is more pronounced among the papers written by male students.

All in all, it is characteristic that the number of persons studying archaeology at universities and university colleges has grown much more than the labour market. Especially in the 1970s this caused trouble for the many students, the first in their families to attend university, who had hoped that the university education would give them not only academic status but also an academic standard of living. They found themselves caught without academic jobs but with loans to be paid. In the long run this has, however, not prevented the number of students of archaeology from rising still more. It is obvious that the hundreds of archaeology students at the Swedish universities and university colleges will never get a position within archaeology, nor will most of them get a position in fields adjacent to archaeology. Most of them also will never get seasonal field-work. This is of course still more evident for the students of classical studies. They have no Swedish labour market at all.

The students today study archaeology because they are interested in archaeology, but if they continue it is not because they see good prospects for a job. Nevertheless, hundreds of them do continue.

\section{EDUCATION AND PROFESSION IN THE 1990s}

What do archaeology students do today after they have finished their education with archaeology as the main subject, after about four years at university or university college with a master's degree including a D-level paper in archaeology?

The 1990s has seen a boom in rescue excavation, and a lot of money has been invested in positions for 1-2.5 years at the national and regional museums in order to organise and catalogue collections and archives. Accordingly, archaeology students that left university before about 1994 have managed fairly well (tab. 7). Their successors will not, and probably many of them will soon move to the "unemployed" column of table 7 .

One student with a permanent job has described her career in the following way. After finishing school she worked one year at the regional museum in her home town, financed by money meant to enable youth to be introduced into the labour market. After that she attended university. Parallel to her university education, she had seasonal jobs at the same museum. Thus, when she left university she was experienced and in addition wellknown at the regional museum. After another two years at the same museum, working in the above-mentioned cataloguing project, she got a full-time permanent position there. Another student living in the same 
Permanent position as archaeologist

Short-term or seasonal job as archaeologist

Jobs related to archaeology or cultural

heritage management (permanent or not)

University, or other, studies

Other kinds of jobs

Unemployed

No answer

Sum
2

8

6

5

5

5

3

9

33

Tab. 7. The present occupation of students that have finished their basic education with archaeology as the main subject at Uppsala University and Mid Sweden University (university college in Östersund) during the 1990 s.

town left university one year after the first student. She has told me quite another story about the insecurity and difficulties in jumping from one short-term job to the other, especially if you eagerly want to work as an archaeologist. Only short-term jobs and mostly seasonal field-work are available. In addition, being the mother of a small child does not make things easier. She sees few prospects of a satisfactory future in archaeology.

\section{CONCLUSION}

It is said that the 1990s was a decade of education: that is formal education, i.e. degrees, and informal education, i.e. knowledge and skill. Education is said to be the key to positions and prestige. The emerging elite has not only the necessary economic resources and social network to enter the elite but also qualifications based on formal education. I am not sure this view is valid for archaeology.

To do a good job as an archaeologist, very much is based on experience. On the other hand, it does not hurt if the experience is organised within a prolific conceptual framework, and the straightforward way to aquire that is to get a university degree.

When I meet my former students, they seem to have two opposite opinions. Some stress that their employers prefer future em- ployees with a university degree with a relevant set of subjects and a seminar paper that demonstrates that the student is able to do an independent work project. Others stress that the employers are more or less only interested in students and employees that can efficiently finish the job at hand, that is, they have satisfactorily done the same kind of job several times before and they are expected to do it once again and nothing else. I do not know which view is the most common one today, or wether there is a change on the way. Anyhow, I think that the future of Swedish archaeology is not dependent on the minority of archaeology students that will manage to enter the labour market to become archaeologists. Those that fail will form the future.

Now and then I get a visit from a former A-level student of mine. Last time she told me that she will soon have finished her university education in pedagogics and psychology, simultaneously to running a small therapy consultation firm and being a parttime shop-assistant. She is not just a sweet person, whom I tend to give a reprint or book, but she is typical of thousands, in the near future, tens of thousands of Swedes. She has a keen interest in archaeology, she has studied archaeology at a university college, but she has an occupation that does not include archaeology, and she certainly never will get 
one that does.

These persons look at archaeology on TV, they purchase archaeology books, visit exhibitions, attend lectures and courses, and they join local archaeological societies. An increasing number of them make excursions and do field-walking. They discover hundreds of flint scatters and other kinds of Stone Age sites. Some of them specialise in discovering new rock-carvings and rock-paintings. Their knowledge of the local landscape helps them record previously unknown pit-falls, Saami hearths, slag-heaps and so on in the hundreds. Some form groups and conduct excavations together with the professional staff at the regional museums. Others form informal research teams that specialise in mapping track-roads, deserted $19^{\text {th }}$-century crofter's holdings, shielings or whatever.

In the next generation there will still be university archaeology, regional museums and cultural-heritage management bureaucracy, but the contents of archaeology will be governed by the presence of the tens of thousands of archaeologically educated persons outside the profession. The whereabouts of the relatively small number of professional archaeologists will be restricted and promoted by the demands and encouragement of a large and well-informed public, and for better or worse the public in the long run will not remain onlookers. A main part of archaeology in Sweden, in the next generation, will be conducted by interested, and often archaeologically university-educated, individuals and informal groups with no professional positions.

\section{English revised by Laura Wrang.}

\section{ACKNOWLEDGEMENTS}

The article is based on in-depth discussions with Gunlög Graner, Elinor Gustafsson, BertOla Henriksson and Rosita Bångåsen, former archaeology students at Uppsala University and Mid Sweden University. Included in the article are also ideas from the D-level papers by Ros-Marie Schönning and Annette Wallin, archaeology students at Mid Sweden University and Lund University. A full list of doctoral degrees confirmed in the period 1850-1998 has been compiled by Anders Carlsson and Jarl Nordbladh, Stockholm University and Göteborg University.

\section{REFERENCES}

Blom, C. 1978. Doktorsavhandlingarna i historia 1890-1975. En kvantitativ studie. Delrapport 8 inom UHÄ-projektet Forskarutbildningens resultat 1890-1975.

Ekholm, G. 1915. Studier i Upplands bebyggelsehistoria I. Stenåldern. Uppsala universitets årsskrift 1916:1. Filosofi, språkvetenskap och historiska vetenskaper 1. Uppsala.

Ferenius, J. 1971. Vårby och Vårberg. En studie $i$ järnålderns bebyggelsehistoria. Theses in NorthEuropean Archaeology. Series B. Theses and papers published in offset 1 .

Gräslund, B. \& Almgren, B. 1976. Archaeology, with special reference to Northern European archaeology. In: Uppsala University 500 years, del 5. Almqvist \& Wiksell International, Uppsala. Pp. 5-10.
Gunnarsson, B.-L. 1989. Facktexter under 1900talet 2. Metoder för textanalys på makro-och mikronivå. FUMS rapport 145.

Iregren, E. 1972. Vårby och Vårberg 2. Studier av kremerat människo- och djurbensmaterial frä järnåldern. Theses and papers in NorthEuropean archaeology 1.

Jonsson, K. 1987. The new era. The reformation of the late Anglo-Saxon coinage. Kungl. Vitterhets-, Historie- och Antikvitets Akademien. Stockholm.

Kyhlberg, O. 1982. Arkeologi i Norden under 1900-talet. En bibliografisk analys av doktorsavhandlingarna från 1897-. Arkeologiska rapporter och meddelanden från Institutionen för arkeologi vid Stockholms universitet 12. Lamm, J.P. 1972. Seminar papers and licentiate 
theses. Unprinted papers. In: Stenberger, M. \& Hedvall, A. (Eds). Swedish archaeological bibliography 1966-1970. Almqvist \& Wiksell, Stockholm. Pp. 319-331.

- 1978. Seminar papers and licentiate theses. Unprinted papers. In: Janson, S. \& Thylander, H. (Eds). Swedish archaeological bibliography 1971-1975. Svenska arkeologiska samfundet, Stockholm.

- 1984. Swedish seminar papers in archaeology 1976-1980. Arkeologiska rapporter och meddelanden från Institutionen för arkeologi vid Stockholms universitet 16

Lamm, J.P. \& Spetz, J.E. 1994. Swedish seminar papers in archaeology 1981-1990. Stockholm Archaeological Reports 28.

Lithberg, N. 1914. Gotlands stenålder. Stockholm.

Lundström, A. 1971. Helgö-studier 1. Frågor kring handel, hantverk och samhälle. Studies in North-European archaeology B:2.

Lundström, L. 1973. Bitsilver och betalningsringar. Studier $i$ svenska depåfynd från vikingatiden påträffade mellan 1900 och 1970. Theses and papers in North-European archaeology 2.

Magnusson, G. 1991. Fornminnesinventeringen - av tradition en männens värld. K.A.N. 12 . Pp. 61-63.

Nordbladh, J. 1991. Kvinnor - män i universitetsvärldens arkeologi. K.A.N. 12. Pp. 45-55.

Odén, B. 1991. Forskarutbildningens förändringar 1890-1975. Lund University Press, Lund.

Rundkvist, M. 1998. Swedish seminar papers in archaeology 1991-1996. Stockholm Archaeological Reports 34.

Rydbeck, O. 1943. Den arkeologiska forskningen och historiska museet vid Lunds universitet under tvăhundra år. Meddelanden frän Lunds Universitets Historiska Museum 1943. Lund. Pp. 1-129.

Rydh, H. 1919. Dosformiga spännen från vikingatid. Stockholm.

Sahlström. K.E. 1915. Om Västergötlands stenåldersbebyggelse. Stockholm.

Schönbeck, B. 1958. Museet för nordiska fornsaker 100 år. Tor 4. Uppsala. Pp. 5-25.

Stjernquist, B. 1984. 180 years (1805-1985) of archaeological research at the Historical Museum of the University of Lund. Meddelanden från Lunds Universitets Historiska Museum 1983-1984. Lund. Pp. 138-173.

Wahlberg, C.G. 1877. Förteckning öfver offentligen försvarade Akademiska Afhandlingar vid Kongl. Universiteten $i$ Upsala och Lund (1852-1877), Kongl. Carolinska MedikoKirurgiska Institutet i Stockholm (1842-1877) och Kejserl. Alexanders-Universitetet i Helsingfors (1853-1877) jemte de under samma tid vid dessa högskolor utgifna program. Esaias Edquist, Upsala.

Welinder, S. 1971. Tidigpostglacialt mesoliticum i Skåne. Acta Archaeologica Lundensia. Ser. in $8^{\circ}$ minore 1.

- 1991. Grundutbildningen vid Stockholms universitet. K.A.N. 12. Pp. 39-42.

- 1995. Training and education in archaeology. Sweden. SIGMA European Universities' Network. Education and Training in Europe. Archaeology. European National Reports. Thessaloniki Conference. May 12-13, 1995. European Commission DG XXII.

- 1998. Gabriel Gustafson i Norge. Viking 1998. Oslo. Pp. 7-35 